\title{
Portraying the Protagonists: A Study of the Use of Adjectives in Harry Potter and the Deathly Hallows
}

\author{
Hishamuddin Salim (Corresponding author) \\ English Language Department, Faculty of Languages and Communication, \\ Sultan Zainal Abidin University, Gong Badak Campus,21300, Kuala Terengganu, Terengganu, Malaysia \\ E-mail: hishamuddin@unisza.edu.my \\ Nadia Nabila Saad \\ Faculty of Languages and Communication, Sultan Zainal Abidin University,Gong Badak Campus,21300, Kuala Terengganu, Terengganu, Malaysia \\ E-mail: nadianabilasaad@gmail.com
}

Received: 22-06-2016

Published: 01-11-2016
Accepted: 26-08-2016

doi:10.7575/aiac.ijalel.v.5n.6p.259
Advance Access Published: September 2016

URL: http://dx.doi.org/10.7575/aiac.ijalel.v.5n.6p.259

\begin{abstract}
The protagonists play important roles in any novel. In J.K. Rowling's Harry Potter novels, they were presented in the most vivid of ways so as to make the characters alive and memorable. One of the strategies used by the author to make the protagonists so lively is through the use of adjectives. This study was conducted to find out the frequency of adjective that was used to describe three protagonists in the novel Harry Potter and the Deathly Hallows. These adjectives are then divided into two categories for easier scrutiny which are features and traits. A further analysis was done to see whether the usage of these frequently recurring adjective could contribute to the depiction of heroic characters. The analysis was done by using concordancer tools called AntConc 3.2.4 and CLAWS. The result of this study shows a very distinctive recurring adjective for each characters which suggest that each one of them are a different unique entity. However, further examination suggest that by looking at the character's adjectives alone would not be intuitive in finding the deeper characterization of these individuals. More parts of speech must be considered, such as verbs and adverbs, for future analysis so as to get a deeper understanding of these characters.
\end{abstract}

Keywords: corpus linguistics, adjectives, Harry Potter and Deathly Hallows, character analysis

\section{Introduction}

The Harry Potter series is a well-known multi-million fan based fantasy novel written by J.K Rowling (Entertainment Times, 2013). It consists of seven novels, translated into 73 foreign translations and has been made into eight movies thus far. The series is about an orphan boy named Harry Potter, who was forced to live with his awful relatives that hated anything 'freaky' or out of the norm. Harry only finds out he is a wizard on his $11^{\text {th }}$ birthday when he was accepted into Hogwarts School of Witchcraft and Wizardry. In this school, Harry meets his two best friends, Hermione Granger and Ronald Weasley and proceeds to have quests to battle the malicious Voldemort and his band of evil followers; the death eaters.

Judging from their role in the story, characters may be classified into two, which are main character or the protagonist and the supporting characters (Priyanti 2016).Throughout the series, Rowling had presented the protagonist in a way that makes these characters come to life and become so memorable that the readers keep coming back for more. There are many scholars who believe the Harry Potter's main success was due to Warner Bros and Bloomsbury'sclever and creative marketing strategies (Patel, 2006; Blake, 2002; Zipes, 2001; Bailey, 2006) but too few have considered the contents of the book itself, especially on how the protagonist is portrayed by Rowling, as being a deciding factor to the series' various achievements in grasping the readers' attention.

Thus, the present study was conducted to gauge the validity of whether character portrayal in the Harry Potter series could be the main reason in seizing the readers' attention instead of marketing techniques done by global corporations. This study is done by analyzing three main protagonists in the final novel of the Harry Potter series which is the Harry Potter and the Deathly Hallows. It incorporates two concepts which is stylistic analysis and corpus analysis, where the corpora of the final Harry Potter novel is analyzed based on these two approaches to study one linguistic feature, which is adjectives that was used by Rowling in describing the three main protagonists in the final novel. The results of the adjectives analyzed are then categorized into three smaller segments for easier scrutiny which are features, emotions and traits. Finally, from these results, the researcher analyzeswether the usage of the frequently recurring adjective could contribute to the depiction of protagonist as heroic characters.

\section{Method}

Stylistics Analysis or Corpus Analysis is referred to the study of the language used in a text (Ericsson, 2013). Ericsson stated that there are numerous things to investigate in the study of a literature text, which are: grammar (both general 
and specific grammatical traits), number of words used, word length, sentence length, metaphors, similes and various more. The connection between language and literature is essential in the study of corpus analysis because a work of fiction is a communication between the author and the reader, and this communication is done through a singular one way communication - which is written language. In this form of communication, the linguistic feature in a novel is important since it conveys the author's intention, feeling and meaning to the readers (Ericsson, 2013).

One of the main reasons for studying an author' writing style is explained by Leech and Short (2007) as “examining the language of a literary text can be a means to a fuller understanding and appreciation of the writer's artistic achievement". The act of studying the variation of style used by authors will let analysts lay the elusive quality of good writing open to inspection, which help other authors not only fingerprint the authors unique style but to also understand the context and nature of the story better (Leech \& Short, 2007). From here, the analyst would get a fuller understanding as to how the authors writing style could bring the story or characters come to life for the readers.

For the Harry Potter phenomenon, Bailey (2006) stated that Harry Potter novels by Rowling had managed to spark an interest in reading among an entire generation of youth. Brown (2002) argues that although many readers might be tempted to dismiss Harry Potter as a passing marketing fad, yet another in a long line of preteen obsessions, it is unwise to do so, since after more than 15 years being on the shelves, the Potter universe is still going strong with an estimated figure of " $\$ 15$ Billion dollars for the Harry Potter Brand's worth with $\$ 450$ million numbers of Harry Potter books in print worldwide" (Entertainment Time, 2013). Thus, this is why there is a rise in the number of academicians seeking to study the Harry Potter phenomenon and find the reasons for its success.

Goatly (2004), who is known to be one of the pioneers for corpus based study for Harry Potter, had analyze the concordance data of the first Harry Potter book according to transitivity systems of Systemic Functional Grammar (SFG). In terms of adjectives usage, there was only a small mention of how adjectives connected to the subject may give the characters a negative quality to them (Goatly, 2004). In another study done by Nygren (2006), he sought to study whether the usage of adjectives could help readers pinpoint heroic or villainous characters and he also highlight what type of adjective were normally used to indicate these characters belonging to which particular category, either a hero or a villain. Nygren had discussed how a character's physical appearance is described to sway the readers into thinking the characters are good or evil and that the choice of particular adjectives does contribute directly to the depiction of heroic or villainous characters (Nygren, 2006).

Since there are few researchers studying the usage of adjectives in contributing to the main character's appeal, and even fewer still that study them with relation to the popularity of the book, this study attempts to see how adjectives were used by Rowling to bring the main protagonists come to life and win the heart of millions of readers all over the world.

This corpus based study focuses on analyzing only the adjectives in the final Harry Potter book Harry Potter and the Deathly Hallows. A digital format was found and then converted into plain text format (.txt). Afterwards, the corpus was then tagged by using a software called CLAWS - which is a free part-of-speech software developed by UCREL that tags the words inside the corpus according to its parts-of-speech. CLAWS has consistently achieved 96-97\% accuracy (the precise degree of accuracy varying according to the type of text).

These tagged data is then put into the concordancer tool call AntConc 3.2.4 and the results are obtained by keywords, concordance and N-frequency.AntConc 3.2.4 is developed by Antony Laurence from the University of Waseda, Japan where this linguistic concordancer automatically constructs a concordance (listing the corpus in alphabetical contexts) for the target corpora (Mukherjee, Künstler, Maiwald, \&Saage, 2005). Mukherjee et al. (2005) also explain that concordancer works much the same way as an internet search engine where "you type in the word/pattern you are looking for, and what the concordancer does is search the corpus for this word/pattern and list all the instances in the middle of your computer screen with some context before and after".

Data obtained from AntConc 3.2.4 is then further segmented into smaller categories which are features, emotions and traits by using an adaption of WALTeR framework for analyzing characters in a novel. Since there are over two hundred adjectives used by Rowling throughout the final novel, the study focuses only on analyzing the top 100 adjectives with its relevance being tied to the three protagonist being analysed which are Harry Potter, Ronald Weasley and Hermione Granger.

\section{Results}

The most striking result to emerge from this data is the total amount of adjectives and adverbs used by J.K Rowling. The researcher would like to point out that the amount of adverbs usage by Mrs. Rowling in this novel is significantly higher than the amount of adjectives that were used, with a difference of 2,864 tokens. To compare this findings to previous research done by Mahmood, A., Mahmmod,R. \& Nawaz (2014) on their corpus analysis of the adjectives in Sidhwa's fictions, they had reported that the author in their study had had a large preferences in using adjectives rather than using adverbs to describe situations or characters. These researchers have substantiate their finding with an argument that a "female linguistic behavior is generally characterized by overstatements and exaggerations, which could lead to the usage of many descriptive words".

Even so, for this current study we could see that this might not be the case for JKR's style of writing. Her role of a female writer, however true or untrue the case may be for female writers to exaggerate while writing, did not affect her style of writing when dealing with the final book. Throughout the whole analyzing process of the corpus analysis, the researcher believe that the usage of adjectives were adequate according to the requirement of the text's situation. This is because the final book has a face-paced tempo with many drama induced plots and sub-plots occurring within its 
storyline. Characters are always on the move since they are being chase by the villains of the novel, therefore, they can hardly sit in a particular place long enough to notice the environments all around them.

Below is a table representing the adjectives used and their frequency.

\begin{tabular}{lll}
\hline Rank & Adjectives & Frequencies \\
\hline $\mathbf{1}$ & Dark & 171 \\
\hline $\mathbf{2}$ & Other & 169 \\
\hline $\mathbf{3}$ & Sure & 163 \\
\hline $\mathbf{4}$ & Old & 160 \\
\hline $\mathbf{5}$ & Great & 149 \\
\hline $\mathbf{6}$ & Little & 144 \\
\hline $\mathbf{7}$ & Good & 124 \\
\hline $\mathbf{8}$ & Long & 113 \\
\hline $\mathbf{9}$ & Small & 107 \\
\hline $\mathbf{1 0}$ & Sorry & 98
\end{tabular}

From the table, it can be seen that by far the greatest frequency of adjective used by Rowling are Dark with a total of 171 frequency, followed by Other, Sure and Old at 169, 162, and 160 total frequency respectively. Among the lowest frequency of adjectives used by Rowling are Good, Long, Small and Sorry at 124, 113, 107 and 98 total frequency correspondingly.

In the corpus of Harry Potter and the Deathly Hallows, the most frequent adjectives to describe the three main protagonists within the book according to three main attributes of Features and Traits are presented in the table below. A detailed analysis of some of these adjectives is given later in order to establish their impact on the depiction of heroic characteristics in the novel.

\begin{tabular}{|c|c|c|c|}
\hline Attributes & Harry Potter & Hermione Granger & Ronald Weasley \\
\hline Features & $\begin{array}{ll}\text { - } & \text { Green eyes } \\
\text { - } & \text { Black Hair } \\
\text { - } & \text { Faint Scars }\end{array}$ & $\begin{array}{ll}\text { - } & \text { Busy Hair } \\
\text { - } & \text { High Voice }\end{array}$ & $\begin{array}{ll}\text { - } & \text { Red Hair } \\
\text { - } & \text { Tall } \\
\text { - } & \text { Lanky } \\
\text { - } & \text { Pale }\end{array}$ \\
\hline Traits & $\begin{array}{ll}\text { - } & \text { Gallant } \\
\text { - } & \text { Gryffindor } \\
\text { - } & \text { Brave } \\
\text { - } & \text { Courageous }\end{array}$ & $\begin{array}{ll}\text { - } & \text { Genius } \\
\text { - } & \text { Brilliant } \\
\text { - } & \text { Fierce } \\
\text { - } & \text { Mudblood }\end{array}$ & $\begin{array}{ll}\text { - } & \text { Determined } \\
\text { - } & \text { Encouraging }\end{array}$ \\
\hline
\end{tabular}

\section{a. Features}

In features, which are the frequent recurrent adjectives that describe the physical appearance of the three main protagonists, is listed above.

In the case of Harry Potter, the analysis of the corpus have shown that the most frequent and distinctive use of adjectives to describe Harry's features were his green eyes and black hair as per the example below:

$$
\begin{aligned}
& \text { "The green eyes found the black ..." } \\
& \text { "...her green eyes, so like his ..." } \\
& \text { "His black hair reached his shoulders" }
\end{aligned}
$$

The mention of his green eyes have much reference to the likeliness of it to his mother's eyes, whom also had had the same colored eyes as his, to which other characters in the book make it a habit to inform Harry of this fact whenever they see him. People had remembered Harry's mother to be a brave and kind witch who fought valiantly against Lord Voldermort and died protecting her son. Her sacrifice had always been a symbol of bravery and it is suggested in the book that people see Harry in much the same way others had seen Lily by those eyes. 
Another interesting adjective that was frequently used is faint scars. The usage of the adjective faint which describes more about Harry's scars signifies that the main character have been through a lot of injuries over the last few years due to Voldermort and his schemes. This reasoning could be also translated for the usage of adjectives with Harry's attire in which Harry had a singed hole in his jeans and his clothes were very badly dirtied during his travels to destroy Voldemort's Horcruxes.

Meanwhile, in the case of Hermione Granger, the most recurrent adjective for this category is her ever present bushy hair as some avid readers might have already known since it describes her main physical appearance throughout the Harry Potter series and in actuality, this particular discovery is not really intuitive in finding out its relevance to our study's objective.

Hermione also is depicted to speak in a high voice and her voice is described using other adjectives synonymous to it such as shrill, high-pitched and loud to show her indignation with something. From further in depth look at the corpus, this is due to Hermione's temperament of quickly getting angry because the situation of the final book is relatively more dire than its previous counterparts with its painful and challenging journey the golden trio had to endure. For example, in the following sentences:

"Lost an -- ?" repeated Hermione in a high voice (acting indignant).
"But then you've got to close your mind!" said Hermione shrill voice (angry).

In the character Ronald, the frequent adjectives related his physical description throughout the series which is having the well-known red hair, tall, lanky and has a pale complexion.

From the findings, there are features that are already centralized to each protagonist that readers would straight away recognize which features these adjectives belong to such as Harry's customary green eyes and black hair, Hermione's bushy hair and lastly, Ronald's red hair as well as his tall and lanky features. These adjectives are not really an immense influence in depicting them as heroic characters but it does give them familiar distinctive differences amongst each other that readers could immediately identify. Nevertheless, there are recurring adjectives to emerge that might tip the scale in portraying them as heroes such as faint scars, high (indignant) voice and pale features. These adjectives showcase the characters undergoing through tough ordeals which gives the subconscious impression to readers that they are strong (to bear scars), yet do feel afraid (pale and high voice) with the ordeals they are facing.

B. Traits

The frequent recurring adjectives to occur under traits are the most significant aspect in marking the protagonist as heroic characters in this corpus analysis. Harry, Hermione and Ronald are mostly described with positive adjectives that portray them as idealistic and typical heroes in the good vs evil spectrum. Some examples of the words used to describe their heroic characteristics are brave and courageous for Harry, genius and brilliant for Hermione and determined and encouraging for Ronald.

Harry Potter's character was described using the adjectives Gallant, True Gryffindor, Brave and Courageous. All these traits means the same thing, which further emphasizes the point that everything Harry had done and accomplished during the Deathly Hallows book shows that he is highly considered by others to be a brave person to be able to achieve what no man even dream to do. Harry had completed all the difficult tasks set out for him bravely, while facing a cruel and evil dark lord who was always trying to kill him due to the prophecy that deemed that no one can live, while the other survives. An interesting display of bravery that the researcher finds highly notable when doing the corpus analysis on Harry is when he had had a surge of pure gallantness protecting a teacher's honor when said teacher was being violated by a death eater, even though to do so would mean he was revealing the location of hiding place to everyone. An excerpt of this act from the corpus can be read below.

"It's not a case of what you'll permit, Minerva McGonagall. Your time's over. It's us what's in charge here now, and you'll back me up or you'll pay the price."

And he spat in her face.

Harry pulled the Cloak off himself, raised his wand, and said, "You shouldn't have done that." As Amycus spun around, Harry shouted, "Crucio!"(....)

"Potter, that was foolish!"

"He spat at you," said Harry

"Potter, I --- that was very --- gallant of you --- but don't you realize --?”

"Yeah, I do," Harry assured her.

Hermione on the other hand was described with the recurring traits: Genius, Brilliant, Fierce and Mudblood. The adjectives genius and brilliant are all complements bestowed on Hermione for her quick thinking and brilliant mind. Even though she's a Gryffindor, her thirst for knowledge shown all through the seven books have proved useful on their 
journey. This is because much of the charms that was truly useful for them was not learned from classroom but from the extra reading did by Hermione as can be seen in the excerpt below.

"But I've never down a Memory Charm."

"Nor have I," said Hermione, "but I know the theory." She took a deep, calming breath, then pointed her wand at Dolohov's forehead and said, "Obliviate." (...)

“Brilliant!" said Harry, clapping her on the back.

The next trait displayed by Hermione is that sometimes she could be fierce towards her friends when she is rather agitated about something, which correlates to her top emotions felt by her being angry. The excerpt below some example of when Hermione display her fierce nature when she is angry.

"Let's see," said Hermione, slamming Travels with Trolls onto the discarded pile with a rather fierce look.

"Obsession?" said Hermione in a low fierce voice.

The last trait that had frequently occurred refers to her blood-status in the magical wizarding world being a mudblood, which means she is not born to magical parents of pure blood. The discussion on mudblood is rather sensitive because the central theme of the book revolves around pure-blood wanting to revolutionize the wizarding world and eliminate all the impurities resulting to the second wizarding war Harry and his friends are facing at the moment.

However, what is most interesting about this particular trait is not on the meaning of it and what it implies to Hermione but to how she reacted to this disparaging label being put on her. She is showing defiance towards the new regime on hunting Mudbloods down set forth by the new ministry that is under Voldermort's control and this shows how courageous Hermione could be. This matter also shows Hermione's ideology regarding the matter where she considers herself equal to half-breed like Griphook the Goblin.

"We do!" said Hermione. She had sat up straight, her eyes bright. "We protest! And I'm hunted quite as much as any goblin or elf, Griphook! I'm a Mudblood!"

“Don't call yourself-” Ron muttered.

"Why shouldn't I?" said Hermione. "Mudblood, and proud of it! I've got no higher position under this new order than you have, Griphook!

The third protagonist, Ronald is depicted using the least number of adjectives with regards to his traits. It can be seen that adjectives within this category are "determined" and "encouraging". Ron had exhibited a sense of determination in his actions and personality, especially when dealing with patching things up with his friends as per the quote provided by Harry below.

"Perhaps because he [Ron] was determined to make up for having walked out on them."

Ron is also quite encouraging when he is not grumpy, tired or hungry. He is often very supportive of his friend's wild view or ideas even though it does not seem logical or downright impossible and when his friend is unable to continue, he knows to step up and encouraging them to move forward such as in the excerpt below. Perhaps because Harry's descent into listlessness galvanized his dormant leadership qualities, Ron was the one now encouraging and exhorting the other two into action.

\section{Conclusion}

To conclude, physical description (features) did not give much insight on the depiction of heroic value seeing as the frequent adjective used in correlation with characters features are very common. From green eyes to red hair, even villains can have those features. Therefore the depictions for physical appearance of heroes based on adjectives used by Rowling are not really conclusive. However, adjectives used for character traits are a strong indicator in depicting heroic characters. This is because the descriptive adjectives used for some characters are quite informative in providing details about the character's behaviour. For example, Harry being the main protagonist is described as gallant, brave and courageous, which are the main traits of a typical hero.

Moving on to emotions, this tricky subject to broach is really not a good indicator to depicting whether a character is a hero or not. Some might find that when analyzing characters to be either a villain or a hero, they believe that characters 
should follow textbooks examples of what a character should feel. For example, a typical villain's emotions should be seen as a person who is constantly always angry and hardly terrified or scared. However, in this analysis we can see the main protagonist frequently recurring emotion as being angry which puts the protagonist in negative light. This, however, hardly makes Hermione a villain since she is angry due to being tired and frustrated of the journey in finding the horcruxes.

Thus, to put forth, an adjective describes under emotion felt by characters are not a conclusive depiction to whether a character is a hero or not. Brown (2002) states that "characters in Harry Potter and the Deathly Hallows are all unique and complex", in which every character is a real human being who feel a wide range of emotions too, and this further help readers empathized with said characters. Rowling had managed to create her characters that are all surprisingly human, who have experienced fear, happiness, love, lost and so much more. From this, readers are more able to relate with the characters and empathize with them more easily.

Furthermore, in some cases, the depiction may not be so clear with certain adjective such as in Hermione and Ronald's trait where there are described as a brilliant and determined person respectively. Being smart and determined could also be a villainous trait as Voldemort, in his youth, is also describe as one of the most brightest wizard of his generation and he was also determined in his quest to power.

All this discussion brings us to the final conclusion which is by looking at adjectives alone; it is not a strong contribution in depicting whether a character is heroic and villainous. Only marginally small does it contributes, but it could not be conclusive to the whole characters being studied. Another more crucial aspect is that these adjective were analyzed in phrases (noun phrases like red hair). If they were to be analyzed just by the adjectives alone, they would have provided a result that is not intuitive in finding the deeper characterization of these individuals. More parts of speech must be considered, such as verbs and adverbs, for future analysis so as to get a deeper understanding of these characters.

\section{References}

Bailey, R. A. (2006). Harry Potter: A modern day hero. School of Communications. St. Louis, Missouri : Webster University.

Brown, S. (2002). Harry Potter and the marketing mystery: A review and critical assessment of the harry potter books. Journal of Marketing, 66(1),

Drouillard, C. (2008). Growing up with Harry Potter: What motivated you to read? Electronic Theses, Treatises and Dissertations, 659. Retrieved from http://diginole.lib.fsu.edu/etd

Eccleshare, J. (2002). A guide to the Harry Potter novels. London: Continuum International Publishing Group.

Ericsson, L. (2013). Fantastic four: A Stylistics Study of Four Authors of Fantasy Fiction.

Garside, R. (1987). The CLAWS Word-tagging System. In R. Garside, G. Leech and G. Sampson (eds.), The Computational Analysis of English: A Corpus-based Approach. London: Longman

Goatly, A. (2004). Corpus Linguistics, Systematic Functional Grammar, and Literal Meaning: A Critical Analysis of Harry Potter and the Philosopher's Stone. Revista Ilhado Desterro.

Knapp, N. F. (2003). In Defense of Harry Potter: An Apologia. School Libraries Worldwide, 9, 78-91.

Leech, G., \& Short, M. (2007).Style in Fiction. United Kingdom: Pearson.

Lennard, A. (2007, February). Harry Potter and the Quest for Values: How the boy wizard can assist young people in making choices. Australia: Australian Catholic University .

Patel, S. (2006). Harry Potterization: The Global Phenomenon Explained. Leonard N. Stern School of Business. New York University.

Priyatni, E. T. (2016). Contradictory Transformation Of Amba Novel: Critical Response With Intertextuality Approach. Journal of Nusantara Studies, 1(1), 46-59.

Ratnasari, N. P. (2014). The Kinds and Functions of Adjectives in the Novel Harry Potter and the Goblet of Fire.Universitas Udayana. Retrieved from http://ojs.unud.ac.id/index.php/sastra/article/viewFile/8046/6061

Time. (2013, July 31). Because It's His Birthday: Harry Potter, By the Numbers. Retrieved from Entertainment Time: http://entertainment.time.com/2013/07/31/because-its-his-birthday-harry-potterby-the-numbers/ on 6/7/2015. 